\title{
House of the dead-exceptional burials of the Avar period (seventh century AD) in Podersdorf am See (Burgenland/A)
}

\author{
Bendeguz Tobias $^{1}$ (D) $\cdot$ Thomas Koch Waldner $^{2}$ (D) $\cdot$ Christina Strobl $^{3}$ (D) $\cdot$ Harald Niederstätter $^{4}$ (D) Christina Musalek $^{5}$. \\ Konstantina Saliari ${ }^{6}$ (i) $\cdot$ Ulrike Töchterle $^{7}$ (1) $\cdot$ Walther Parson ${ }^{8,9}$ (i)
}

Received: 16 May 2019 / Accepted: 29 May 2020 / Published online: 18 July 2020

(C) The Author(s) 2020

\begin{abstract}
A unique archaeological finding of five individuals buried in an early medieval pit house was discovered in Podersdorf am See (Austria). Three of those individuals were buried in narrow grave pits that had been deepened into the house floor; two of them were lying on the pit floor in a crouched position. Pit houses with six-post construction are known since Roman times and were particularly widespread during the Migration Period. On the basis of radiocarbon analyses of charcoal from the hearth, the use phase of the pit house of Podersdorf am See can be dated to the sixth century AD. The burials took place around the same time in the second half of the seventh century AD, when the house lost its original function. Around that time, regular burials took place in the cemetery in the immediate vicinity of the house. The anthropological examination of the five skeletons showed no significant differences in comparison to the ones that were buried in the cemetery. By means of aDNA analyses, it could be established that at least two of the individuals were closely related to each other.
\end{abstract}

Keywords Pit house $\cdot$ aDNA $\cdot$ Anthropology $\cdot$ Early Middle Ages $\cdot$ Crouched burial

\section{Introduction}

A mysterious group of five individuals was buried in an unusual manner in a pit house (sunken featured building) at the edge of the Early Mediaeval cemetery of Podersdorf am See (Fig. 1).

The site is located south of today's village on a flat hill ridge running west and east and in close proximity to the eastern shore of Lake Neusiedl. The surrounding landscape is characterised by its flat relief with a maximum height difference of only $17 \mathrm{~m}$ and countless salt pan lakes.

Bendeguz Tobias

Bendeguz.Tobias@oeaw.ac.at

Walther Parson

walther.parson@i-med.ac.at

1 Institute for Medieval Research, Österreichische Akademie der Wissenschaften, Hollandstraße 11-13, A-1020, Vienna, Austria

2 Deutsches Bergbau-Museum Bochum, Am Bergbaumuseum 31, D-44791 Bochum, Germany

3 Institute of Legal Medicine, Medical University of Innsbruck, Müllerstraße 44, A-6020, Innsbruck, Austria

4 Institute of Legal Medicine, Medical University of Innsbruck, Müllerstraße 44, A-6020, Innsbruck, Austria
The archaeological examination of the Early Mediaeval cemetery of Podersdorf revealed a total of 39 burials of the seventh century AD. The cemetery was established at the time when the Avars ruled the Carpathian Basin, from the second half of the sixth to the beginning of the ninth century AD (Pohl 1988).

Next to this cemetery, on the ridge of the hill, were a number of pit houses (Fig. 2). The largest building, where the five burials were located, was archaeologically examined and is presented in this article.

5 Anthropological Department, Museum of Natural History Vienna, Burgring 7, A-1010 Vienna, Austria

6 First Zoological Department, Archaeological Zoological Collection, Museum of Natural History Vienna, Burgring 7, A-1010 Vienna, Austria

7 Institut of Archaeology - Restoration, University of Innsbruck, Templstraße 22, A-6020, Innsbruck, Austria

8 Institute of Legal Medicine, Medical University of Innsbruck, Müllerstraße 44, A-6020, Innsbruck, Austria

9 Forensic Science Program, The Pennsylvania State University, 329 Whitmore Laboratory, University Park, PA 16802, USA 


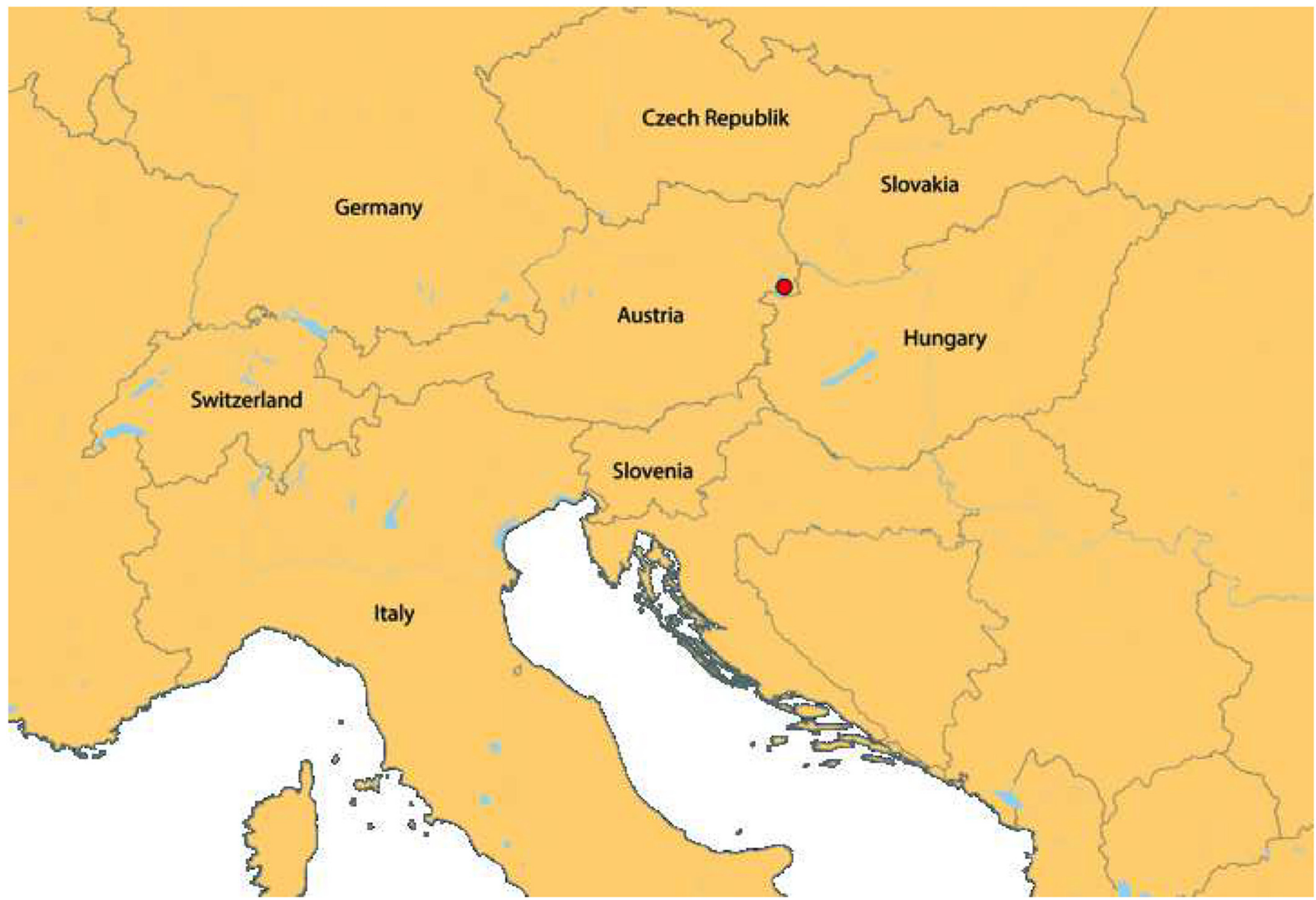

Fig. 1 Location of the site of Podersdorf am See (A) (drawing: Bendeguz Tobias)

Even though more than 60,000 inhumations of the Avar period are known in the Carpathian Basin, the recent finding of Podersdorf am See represents a unique case.

The following article tries to answer several questions regarding these extraordinary findings: When was the pit house used, and at what time was it abandoned? When did the burials take place? Is there a connection between the burials in the house and those in the nearby cemetery? Do the burials in the house differ from those in the cemetery from an anthropological point of view? Are there any family relations between the buried persons?

\section{The pit house}

Next to and within the Early Mediaeval cemetery, several settlement structures, such as pit houses ("Grubenhäuser") as well as rubbish pits, were detected by means of geomagnetic prospection on the hilltop. Two of these structures have been examined in the course of our excavations (Tobias et al. 2018).

The pit house "object 55" was found at the northern edge of the cemetery (Fig. 3). The unusually large building is a sixpost construction.
North of the Danube, especially in Moravia and Slovakia (Beljak and Kolník 2008, pp 65ff p 67 fig 3 p 68 fig 4. p 72 fig 8.1; Kolník 1998, pp 144ff p 145 fig 1.11 p 149 fig 6.5-6; Tejral 1998, pp 181ff p 201 fig 18.14, 202 fig 19), six-post houses such as our main object already occur during the Roman Imperial Period (Beljak and Kolník 2008; Tejral 1998). It should not be forgotten that this house form was found south and west of the Danube in a much earlier context, dating back to the late Latène and Early Roman Imperial Period (Ottományi 2015; Budai Balogh 2009).

South of the Danube, in Eastern Austria, this type of house was found mainly in contexts of late antiquity and the Migration Period. For this reason, some researchers assume that six-post houses are associated with people who crossed the Danube during the fifth century AD and settled on Roman or former Roman territory (Stuppner 2013). However, this theory needs to be re-evaluated in the light of new discoveries and insights. In the last five years, the number of pit houses of this type has increased significantly in today's Western and Southern Hungary (Ódor 2011, pp 355-356 fig 9). It should also be noted that this type of house could still be found sporadically in the sixth and seventh centuries AD (Müller 2018, p 39f fig 4. p 51 fig 12.3; Schoenenberg 2018, p. 180 fig. 6; 


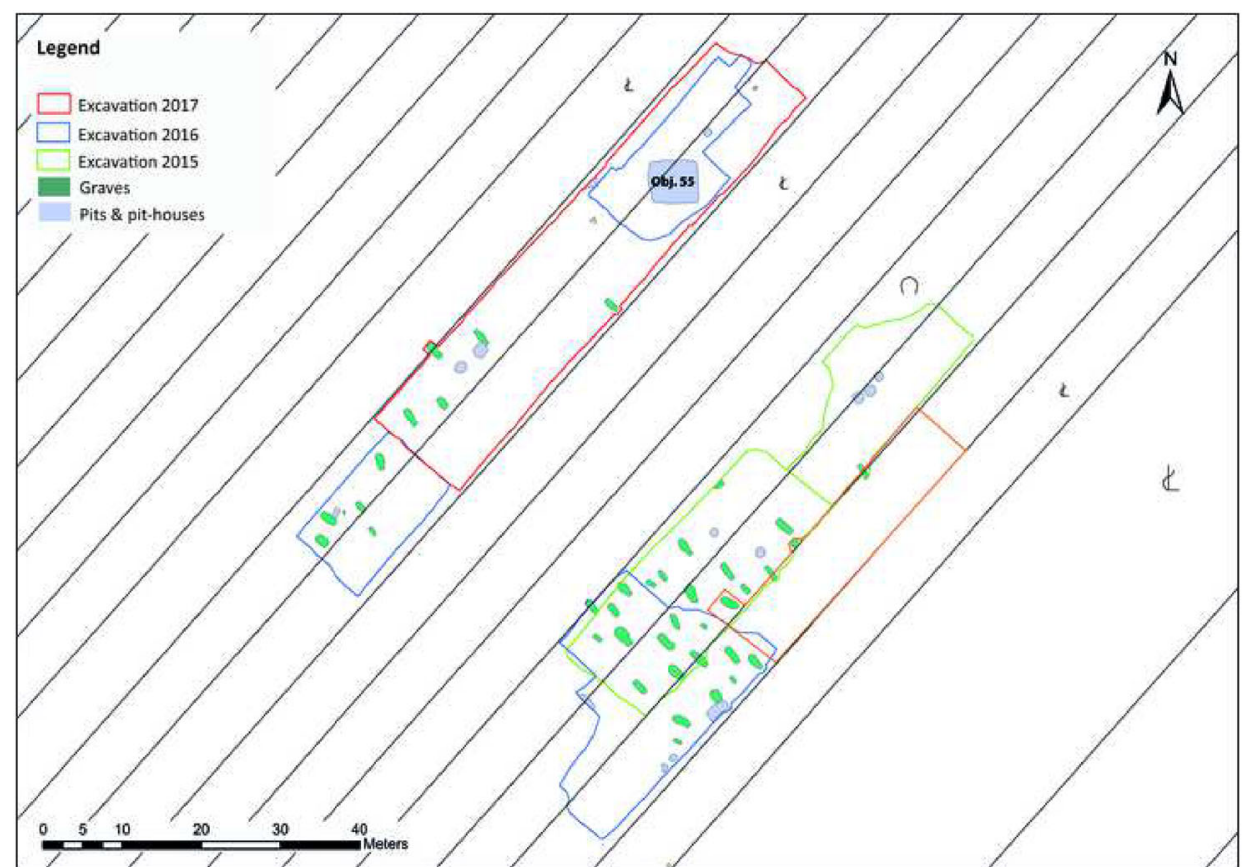

Fig. 2 General plan of the excavation area with the pit house "object 55" in Podersdorf am See (drawing: Thomas Koch Waldner)

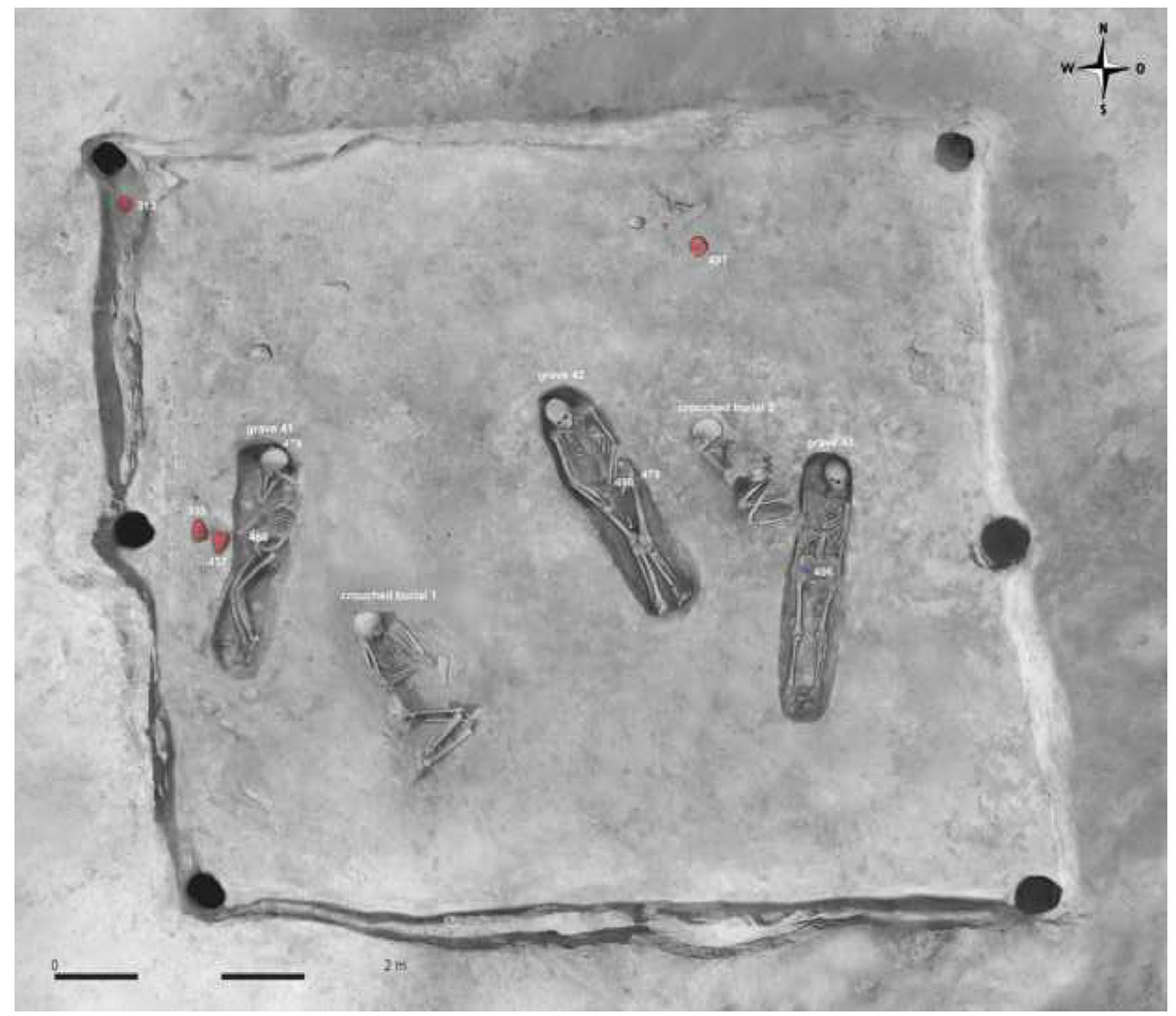

Fig. 3 Six-post house (object 55) with five burials (drawing: Andreas Blaickner, Thomas Koch Waldner, Bendeguz Tobias) 
Fig. 4 Pyramidal loom weights from the floor of the pit house (photos: Andreas Blaickner)

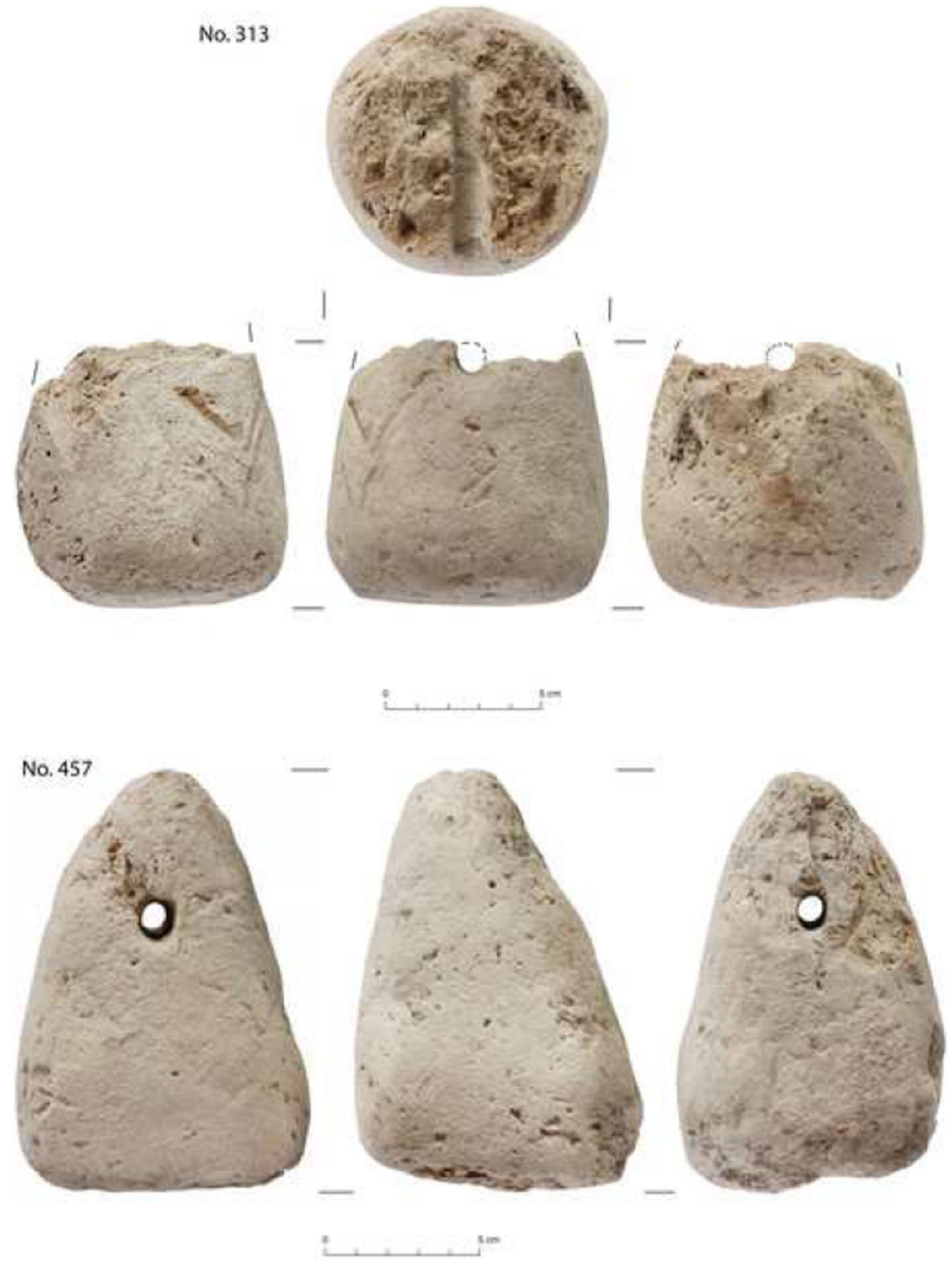

Nice 1994, pp 37-39 fig 6; Винокур and Мегей 1992). Only one pit house from Mannersdorf an der March (Niederösterreich/A) is known from this period in Austria (Wawruschka 2009, p 52f p 110 p 129).

In addition to adjacent areas, this six-post house can also be found east of the River Tisza (Cseh 1999) and even in distant areas such as the Normandy (Hincker 2007, pp 175ff), to name just a few examples.

Finally, it must be emphasised that, concerning its shape and size, the finding from Podersdorf differs significantly from most of the six-post houses. Initial comparisons reveal that this pit house, with its surface area of approximately $30 \mathrm{~m}^{2}$, is twice as large as most of the comparative examples outside the former Roman Empire (Ottományi 2015, pp 122-124; Budai Balogh 2009, p 85 Tab 1, 97-100). In addition, only a few further six-post constructions with an almost square ground plan and North-South orientation have been located so far
(Ottományi 2015, pp 126-130; Budai Balogh 2009, p 85 Tab 1, pp 95-97). Most of the pit houses with three posts on one side and three on the opposite side are rectangular (Budai Balogh 2009, p 94f).

The nearest pit houses with six-post construction were discovered about $9 \mathrm{~km}$ north of the site, in Weiden am See (Burgenland/A), and $15 \mathrm{~km}$ to the west, in Schützen am Gebirge (Burgenland/A) on the other side of Lake Neusiedl. These six-post houses are dated to the Migration Period.

Comparative examples for the building in Podersdorf - in relation to size, shape and orientation-can be found in Pannonia during the Migration Period. The pit house features from Mohács (Baranya county/H) (Párducz 1949) and Mözs (Tolna county/H) (Ódor 2011, pp 355-356 fig 9) as well as the recently discovered settlements in Kaposvár (Somogy county/H) (Ódor 2001), Fonyód (Somogy county/H) (Somogyi 2000, p 246. p 248, fig 9), Ballatonlelle (Somogy county/H) (Skriba and Sófalvi 2004) and Zamárdi (Somogy county/H) 
Fig. 5 No. 335 and no. 194: pyramidal loom weights; no. 445 : grindstone from the floor of the pit house (photos: Andreas Blaickner)
No. 445
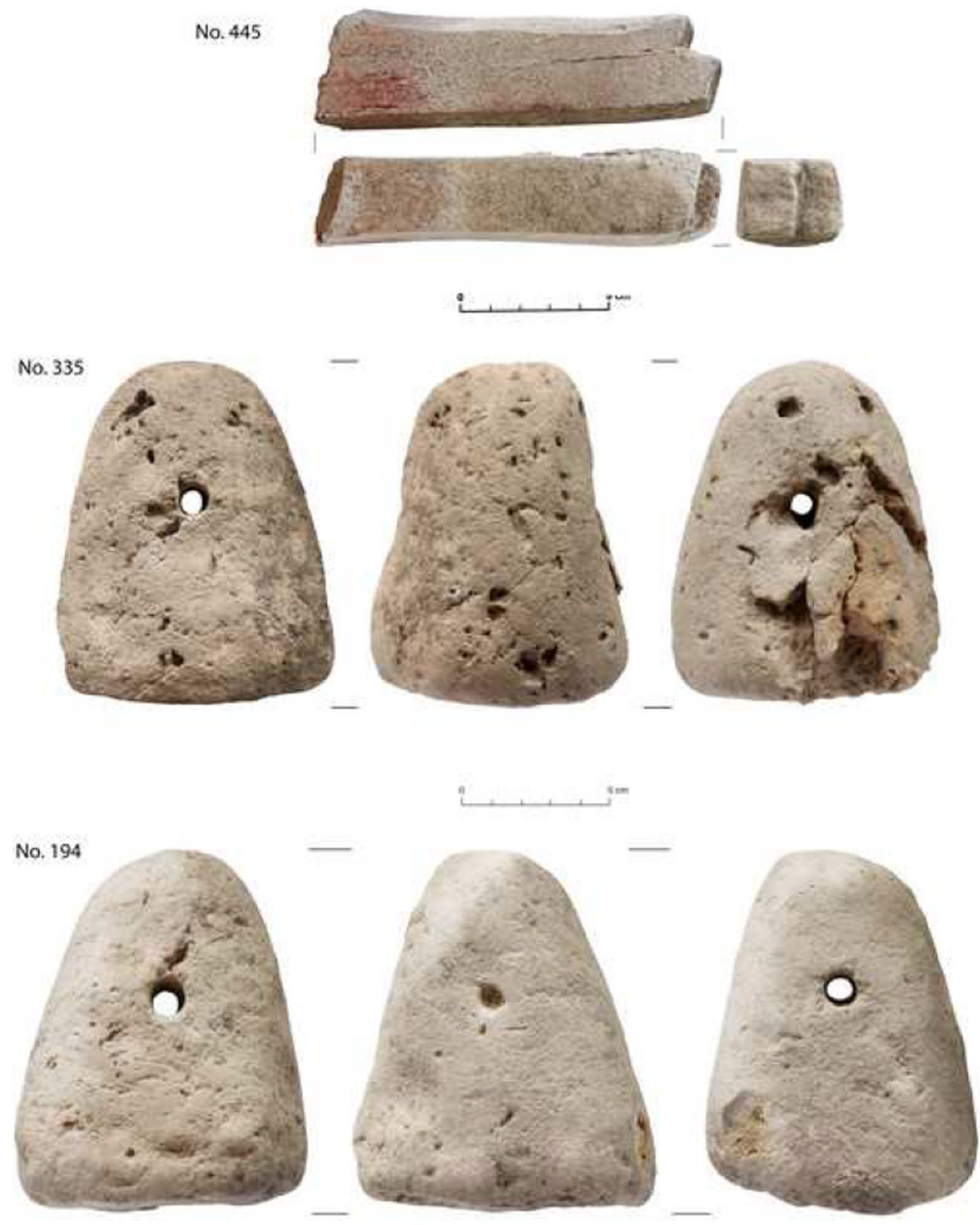

(Bocsi 2008, pp 415-417 fig 3; Kiss 2007, pp 67-68 fig 57-58, p 64) deserve special mentioning. North of the Danube, only one comparative example from Mušov in Moravia is known so far (Tejral 1998, fig 18.1).

\section{Function of the house}

A hearth, loom weights and whetstones found on the floor indicate that economic activities were carried out in the building (Leube 2009, p 51-52). Ceramics and fragments of animal bones from the filling provide indications of the phase of abandonment.

A total of four pyramidal loom weights were found, with two of them lying at the edge of post holes on the west side of the house (Figs. 4 and 5). Pyramidal loom weights are widespread in the Early Middle Ages. Comparative examples nearby can be found in the already mentioned settlements of Weiden am See (Burgenland/A) (Franz et al. 2015, p 174) or Schützen am Gebirge (Burgenland/A) (Herdits 2019, p 29), as well as
Unterlanzendorf (Niederösterreich/A) (Stadler 1981, p 154 p 177 fig 16.4-5), Drösing (Niederösterreich/A) (Jedlicka and Schmidt 1999, p 779 fig 615), Schletz (Niederösterreich/A) (Nowotny 2014, p 248) and Mistelbach (Niederösterreich/A) (Blesl et al. 2009, p 20). Examples for more distant loom weights are known from Rákóczifalva (Jász-Nagykun-Szolnok county/ H) (Masek 2015, p 438 fig 8, 1-3), Iversheim (Stadt Bad Münstereifel/D) (Wirth 2011, p 10 fig 12-13) or Goudelancourtles-Pierrepont (dép. Aisne/F) (Nice 1994, p 54 fig 40).

Furthermore, a grinding stone (no. 445) was found on the floor of the house (Fig. 5). A scan of the surface using microXRF did not reveal any indications of the use of precious metals (copper or silver), but the use of iron is conceivable ${ }^{1}$.

Only very few inconspicuous ceramic fragments came to light in the house (Fig. 6). The manufacturing technique and

\footnotetext{
${ }^{1}$ The examinations were carried out by Thomas Angerer, Institute of Mineralogy and Petrology at the University of Innsbruck.
} 
Fig. 6 Ceramic fragments from the floor of the pit house (photos: Andreas Blaickner)
No. 423

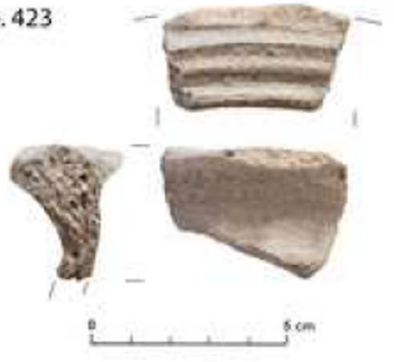

No. 491

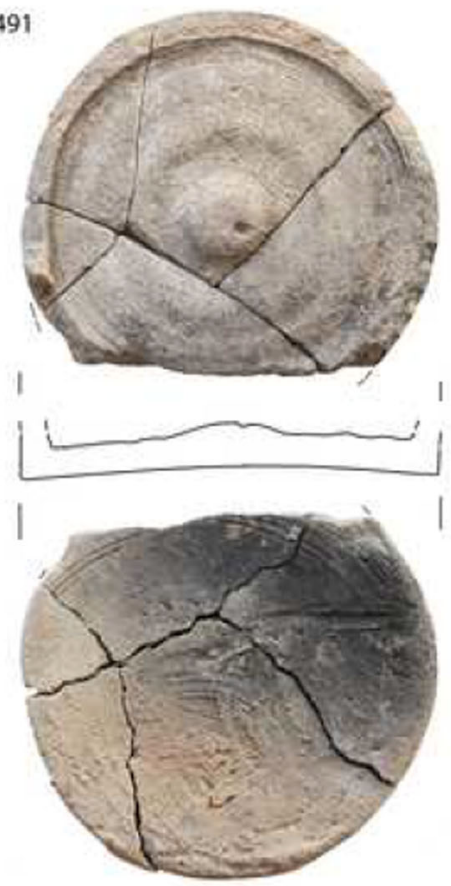

: sin

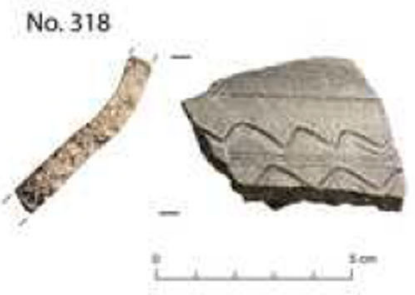

No. 337

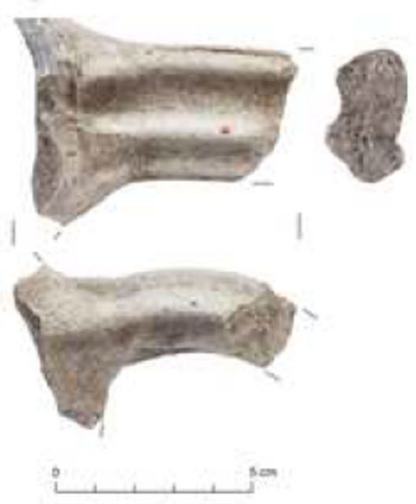

No. 446

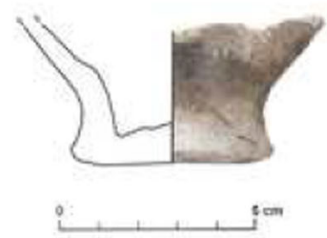

wavy line decoration point to ceramics in the tradition of late antique pottery (Pollak 2017, 257-259). Altogether, the archaeological finds which are connected to the use of the house are not specific enough for a more exact dating of its use phase.

The primary function of the house ended when the structure was used as a burial ground. First, three tombs were dug into the ground. Right after, two other deceased persons were buried in the filling layers formed above the floor level. The stratigraphic position of these two skeletons made it clear that the funeral of the deceased took place after the first use phase of the house. During excavation, there was no evidence suggesting that the burials were subsequently deepened into the already filled pit house. Since the backfilling earth of the grave pits and around the two crouched burials is identical, the backfilling of the house pit and the depositing of the two burials in the backfill must have taken place simultaneously. Animal bones were found, especially in the filling layer above the burials. In total, 38 out of 92 specimens (41.3\%) were identified and analysed (Table 1$)$. The results indicate that the majority of bones derive from horse $(n=13)$ and dog $(n$ $=12$ ), followed by bones of wild birds $(n=9)$, representing at least two individuals, cattle $(n=3)$ and sheep $(n=1)$. Concerning the age at death, the bones of cattle, sheep, horse and wild birds come from adult individuals. The examination of one dog mandible indicates the presence of a very old adult individual. Sex determination could not be addressed due to the lack of material suitable for sexing. Two bones of cattle (a fragment of a metapodium and a tibia fragment) and 15 unidentified fragments indicate exposure to fire. Chop marks and fractures on horse and dog bones suggest consumption.

\section{The burials}

Three of the individuals from Podersdorf (graves 41, 42 and 43) were squeezed into very narrow pits - just about the size of their bodies - in the floor of the house, with their backs 
Table 1 Skeletal element representation of animal species found in the pit house (object 55) (drawing: Konstantina Saliari)

\begin{tabular}{|c|c|c|c|c|}
\hline Element & $\begin{array}{l}\text { Bos primigenius } \mathrm{f} . \\
\text { taurus }\end{array}$ & $\begin{array}{l}\text { Ovis orientalis } \mathrm{f} . \\
\quad \text { aries }\end{array}$ & $\begin{array}{l}\text { Equus ferus } \mathrm{f} . \\
\text { caballus }\end{array}$ & $\begin{array}{l}\text { Canis lupus } \mathrm{f} . \\
\text { familiaris }\end{array}$ \\
\hline Mandibula & & & 1 & 1 \\
\hline Costae & & & 2 & 6 \\
\hline Vertebrae & & & 8 & 1 \\
\hline Scapula & 1 & & 1 & \\
\hline Humerus & & & 1 & \\
\hline Radius & & 1 & & 1 \\
\hline \multicolumn{5}{|l|}{ Femur } \\
\hline Tibia & 1 & & & \\
\hline Metapodia & 1 & & & 3 \\
\hline Total & 3 & 1 & 13 & 12 \\
\hline Element & Wild birds & & & \\
\hline Vertebrae & 1 & & & \\
\hline Radius & 3 & & & \\
\hline Ulna & 1 & & & \\
\hline \multirow[t]{2}{*}{ Femur } & 1 & & & \\
\hline & 1 & & & \\
\hline \multicolumn{5}{|c|}{$\begin{array}{l}\text { Tarsometata- } \\
\text { rsus }\end{array}$} \\
\hline Phalanx & 2 & & & \\
\hline Total & 9 & & & \\
\hline
\end{tabular}

stretched out or, in one case, lying slightly tilted to one side. Two other individuals (crouched burial 1 and 2) were lying in the foetal position on the floor of the house. The bodies of all five persons were oriented North-South and NNW-SSE. Differing from this, the orientation of the graves in the Carpathian Basin of the sixth-eighth centuries was usually West-East or NW-SE. North-South or NNW-SSE-oriented burials are relatively rare during the sixth and seventh centuries in the Carpathian Basin (Balogh 2016, pp 39-42). Within this region, the occurrence east of the river Tisza is more frequent (Bende 2017, pp 250-253). A simultaneous accumulation of this orientation can only be found in cemeteries in the Altai area and in today's Kyrgyzstan (Balogh 2016, p 42). The feotal position of the two burials at Podersdorf is unusual.

In contrast to the burials in the house, the graves of the regular cemetery in the immediate vicinity were almost all systematically reopened. Despite the grave disturbing, some precious objects like a golden earring or a silver-gilt belt fitting were left behind in the grave pits. A significantly high number of male burials were equipped with composite bows, indicating their social status (Tobias et al. 2017, 2020).

Only the three individuals in the house located in the grave pits were accompanied by some grave goods. Simple rectangular iron buckles were added to all three individuals (Fig. 7). Despite the strongly degenerated state of the three iron objects, a few textile remains adhering to their surfaces survived. During the excavations, special attention was paid to these remains, and the finds were recovered en bloc. The difficult task of uncovering them with brushes and needles under the stereomicroscope was performed at the restoration laboratory of the Department of Archaeology, University of Innsbruck. The buckle in grave 43 (no. 496) was located on the right

\footnotetext{
${ }^{2}$ Determination of the textile density was not possible.
}

pelvic blade and had an approximately $30 \mathrm{~mm}^{2}$ big mineralised tabby weave at the front in the area of the point of the prong (Fig. 7c). The diameters of the Z-twisted warp and weft yarns made from a vegetable fibre (linen/hemp) measure $0.9-1.2 \mathrm{~mm}$ and have a coarse quality ${ }^{2}$. The finer tabby weave remnants on the back of the iron buckle (no. 466) from grave 41 reveal a much better preservation (Fig. 7a). The $0.5-$ 0.8-mm-thick Z-twisted vegetable threads form a fabric density of $10 \times 12$ threads $/ \mathrm{cm}^{2}$. The nature of the organic textile layers on the buckle from grave 42 (no. 498, on the left pelvic bone) could not be determined any more due to bad preservation. In general, it can be said that so far only textiles in tabby weave from vegetable fibres have been found on the grave goods from Podersdorf. Typical, however, is the main use of Z-twisted threads (Grömer 2015, p 200). The determination of the fabric densities allows us a general classification of the textiles from Podersdorf into finer (15-19 threads/cm) and coarser qualities (10-13 threads/cm) with average thread strengths of $0.3-0.7 \mathrm{~mm}$, which are rougher than other grave textiles from the Avar period (Grömer 2015; Hundt 1987).

Further grave goods are flint stones (no. 486 and no. 468) from graves 41 and 42 (Fig. 8). In addition, underneath the head of the individual in grave 41 , there was an unornamented bone needle tube (no. 479), and a whetstone was found at the pelvis in grave 42 (no. 478). Needle tubes like the one from grave 41 were in use in Eastern Austria during the period from the second half of the seventh century $\mathrm{AD}$ to the first half of the eighth

\footnotetext{
${ }^{0}$ Radiocarbon analyses were performed in the AMS ${ }^{14} \mathrm{C}$ laboratory of Isotoptech ZRT in Debrecen, Hungary.

${ }^{0} \mathrm{~L}$-temperature fraction and $\mathrm{H}$-temperature fraction.

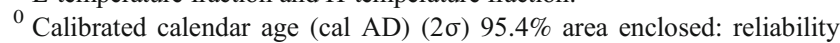
$78.16 \%$.

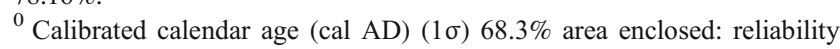
$73.74 \%$.
} 
Fig. 7 Front (left) and back sides (right) of the rectangular iron buckles from the graves 41,42 and 43 with mapping of organic and textile remains (drawing and photos: Ulrike Töchterle and Theresa Hinterkörner)
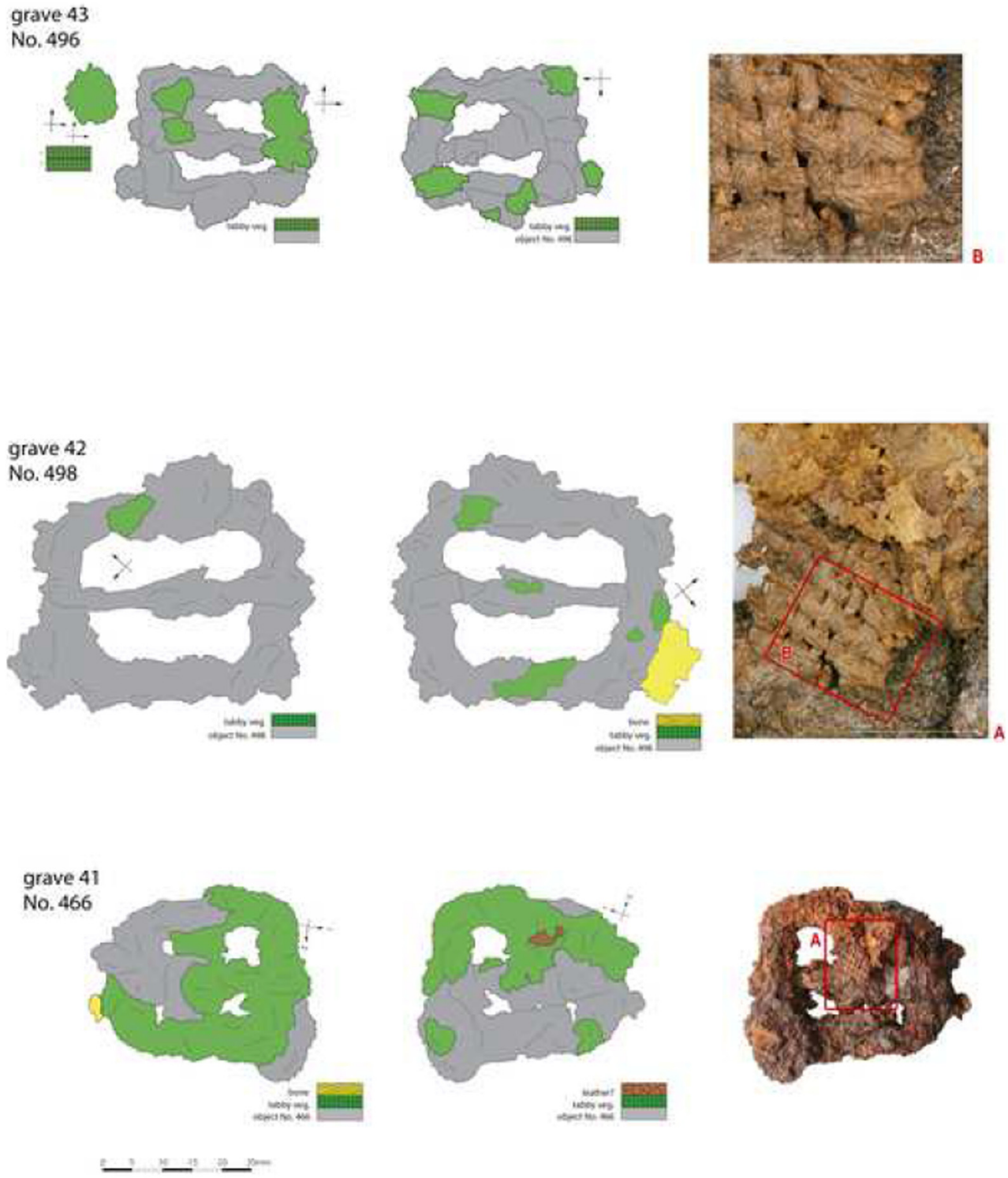

century AD (Distelberger 1999, p 195). The two individuals buried in the crouched position had no grave goods. None of the grave goods are specific enough for dating the burials.

\section{Chronology}

The archaeological finds do not allow a chronological classification in order to date the pit house and the burials. We therefore radiocarbon-dated charcoal fragments from the

\footnotetext{
${ }^{3}$ Radiocarbon analyses were performed in the AMS ${ }^{14} \mathrm{C}$ laboratory of Isotoptech ZRT in Debrecen, Hungary.

${ }^{4} \mathrm{~L}$-temperature fraction and $\mathrm{H}$-temperature fraction.

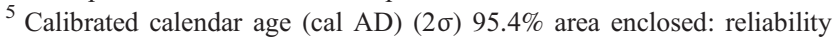
$78.16 \%$.

${ }^{6}$ Calibrated calendar age (cal AD) $(1 \sigma) 68.3 \%$ area enclosed: reliability $73.74 \%$.

${ }^{0}$ On this problem, and for further literature see Toplak 2017, 55.
}

hearth in order to determine the use phase of the house ${ }^{3}$. The measurements under different conditions showed quite a large possible time span of use between the second half of the fourth century $\mathrm{AD}$ until the end of the sixth century $\mathrm{AD}^{4}$. This means that the house was already in use during the Langobard rule and the earliest rule of the Avars in the Carpathian Basin.

Analysis of the skeletons demonstrated that the burials must have taken place in the second half of the seventh century $\mathrm{AD}$ and the beginning of the eighth century AD. Since we must assume - on the basis of the archaeological findings that the burials took place at the same time, we can even limit the period to $662-691 \mathrm{AD}^{5}$ or even $669-673 \mathrm{AD}^{6}$ on the basis of the five radiocarbon samples (Table 2). The result suggests that a longer period of time has passed between the use phase of the house and the burials. However, the charcoal analysis does not allow us to determine the exact time of abandonment. In addition, observations on wooden post constructions in the 
Fig. 8 Flint stones, a needle case and a grindstone from graves 41 and 42 (photos: Andreas

Blaickner)

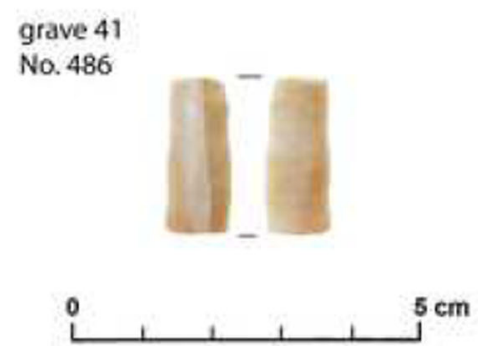

grave 42

No. 468
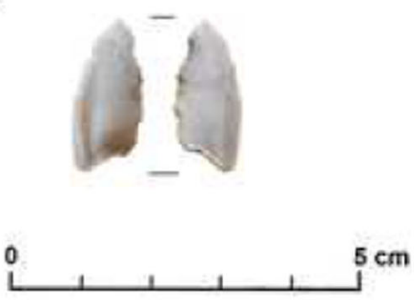

grave 41

No. 479

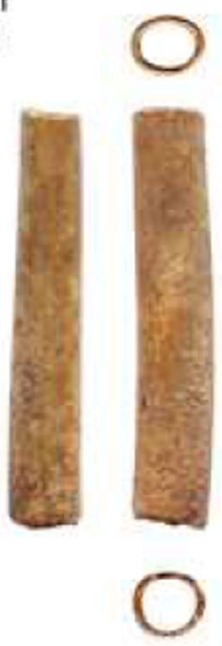

grave 42

No. 478
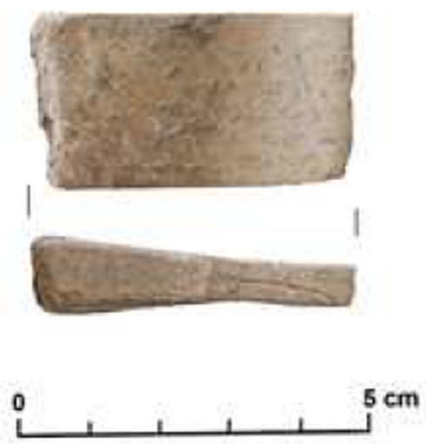

ground show that one can probably assume a durability of about 100 years on a rough average (Schmidt et al. 2005, p 161f). Since the five individuals were placed exactly inside the house, and two of the individuals were lying on the floor, we must assume that the house was still standing at the time of the burials and the floor was clear. The results of the bone analysis clearly show that the individuals were buried in the pit house at a time when the regular cemetery was in use.

\section{The atypical burials}

As far as the burials in the house of Podersdorf am See are concerned, two unusual factors not conforming to rules come together: the chosen place within a building and the special way in which the two individuals are buried in lateral foetal position. Such "standard" of deviant treatment of the deceased in burial rites is usually referred to as "deviant burials" or "special treatments" in the scientific discourse".

\footnotetext{
${ }^{7}$ On this problem, and for further literature see Toplak 2017, 55.
}

In general, burials in dwellings or workshops are rare. These are mainly individual burials for newborns or children (Preinfalk et al. 2013, p 42f fig 13; Obenaus 2015, p 239; Beilke-Voigt 2008). Burials of adults in pit houses are only to be found in exceptional cases (Müller 2012, p 472f; Tóth 2006, pp 19-23 fig 12-13, p 37f fig 22. 23; http:// www.archaeologie-online.de/magazin/nachrichten/ aktuelles-von-der-b6n-slaw is che-siedlung-mithausbestattung-entdeckt-17446/). In some cases, burials of animals such as a horse in a pit house in Seebarn (A) are also documented (Blesl and Preinfalk 2007, p 36 f fig 46). Contrary to the five burials in the house of Podersdorf, the comparative examples always involve single burials. It is difficult to find a common interpretation for the burials within the house (Beilke-Voigt 2008; Beilke-Voigt 2009). First, it must be decided whether the burials represent the end of the use of the house or whether the house was still inhabited. The findings of Podersdorf show that the two burials were deposited on the floor, thus confirming the end of the house's use.

Individuals buried in foetal position are "more common". In the east Austrian region south of the Danube, this 


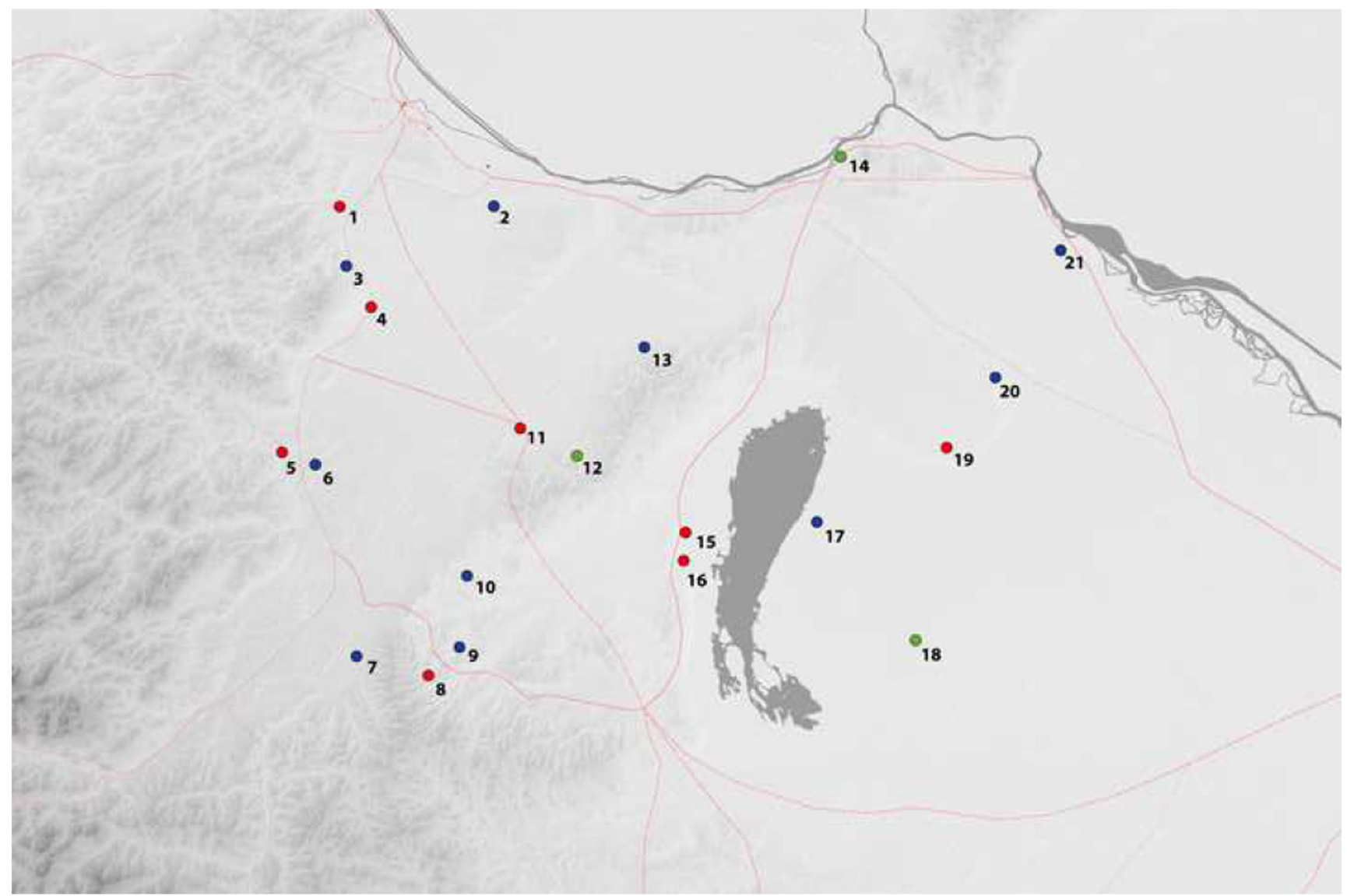

Fig. 9 Distribution of crouched burials in Eastern Austria south of the Danube. Red: Roman Empire and Late Antiquity; Blue: Early Middle Ages; Green: High Middle Ages. 1: Perchtoldsdorf-Aspettengasse (grave 20), 2: Zwölfaxing-Feldsiedlung (grave 37a), 3: Mödling-An der Goldenen Stiege (graves 365 and 538), 4: Guntramsdorf-Henschlgasse (grave 36/1), 5: Hirtenberg-Patronenfabrik (grave 1939/2), 6: Leobersdorf-Ziegelei Polsterer (graves 42, 75 and 147), 7: FrohsdorfKreuz Äcker (grave 488), 8: Wiesen, 9: Sigleß-Kloaschitzwald (object

form of burial, which deviates from the rule, has been known since the Roman Empire (Fig. 9). Evidence of this can be found continuously until the High Middle Ages. In Early Mediaeval cemeteries of the Carpathian Basin, this type of burial only occurs in less than $1 \%$ of all known graves. Most of these cases, 37 burials, are known from the area east of the river Tisza (Bende 2017, p 282). Anthropological studies have shown that this type of burial was not limited to a specific sex or age group (Bende 2017, p 282). It was also observed that none of these burials had food as grave goods (Bende 2017, p 282). The preferred location of these burials,, as in the case of Podersdorf, is at the edge of the cemetery. In addition, it can be stated that hardly any grave goods or jewellery were added to the deceased. There is no generally acknowledged interpretation of the special position: The foetal position can therefore be the expression of a loving burial, combined with the wish of the bereaved that the deceased find a rest similar to sleep
1/24), 10: Zillingtal-Unterer Kapellenberg (graves C124, C143 and C192), 11: Leithaprodersdorf, 12: Stotzing (grave 17), 13: SommereinSteinäcker (grave 111), 14: Bad Deutschaltenburg, 15: Oggau-Triftäcker (grave II), 16: Rust (grave 11), 17: Podersdorf-Winkeläcker (crouched burial 1 and 2), 18: Wallern (grave 51), 19: Halbturn (graves 59, 94, 96 and 99), 20: Nickelsdorf-Akaziengasse, 21: Bratislava-Rusovce (SK) (grave 147) (drawing: Bendeguz Tobias)

(Nießen 2012, p 20). Due to a lack of grave goods or the small number thereof, the deceased were sometimes interpreted as servants or as unfree persons (Obenaus 2010, p 179), and sometimes as members of a different ethnicity (Puschnigg 1996, p 74; Milella et al. 2015, p 11; Kulcsár 1998, p 32). According to mediaeval written sources, this burial position was associated with the protection against "dangerous" dead (revenants and undead) (Brather 2007, p 116).

It is often forgotten that individuals buried in the foetal position, which burials are regarded as "deviant", occur again and again over a long period from the Roman Empire to the Middle Ages. In addition, they are not limited to a small area, but can be found from the Volga to Britain (Milella et al. 2015, p 11; Kulcsár 1998, p 32). Accordingly, it seems almost impossible to find a uniform interpretation for the intention behind the foetal position in the burial ritual. 


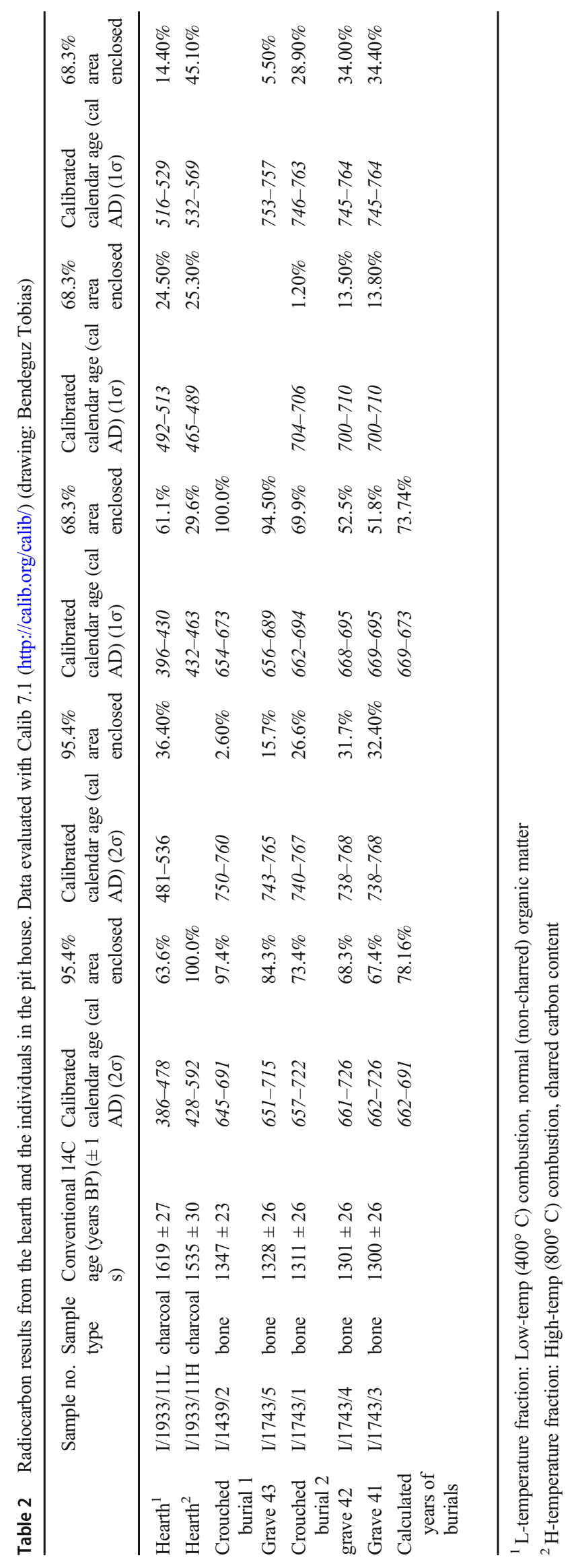


Fig. 10 Sex and age-at-death distribution $(n=34)$ (drawing: Christina Musalek)

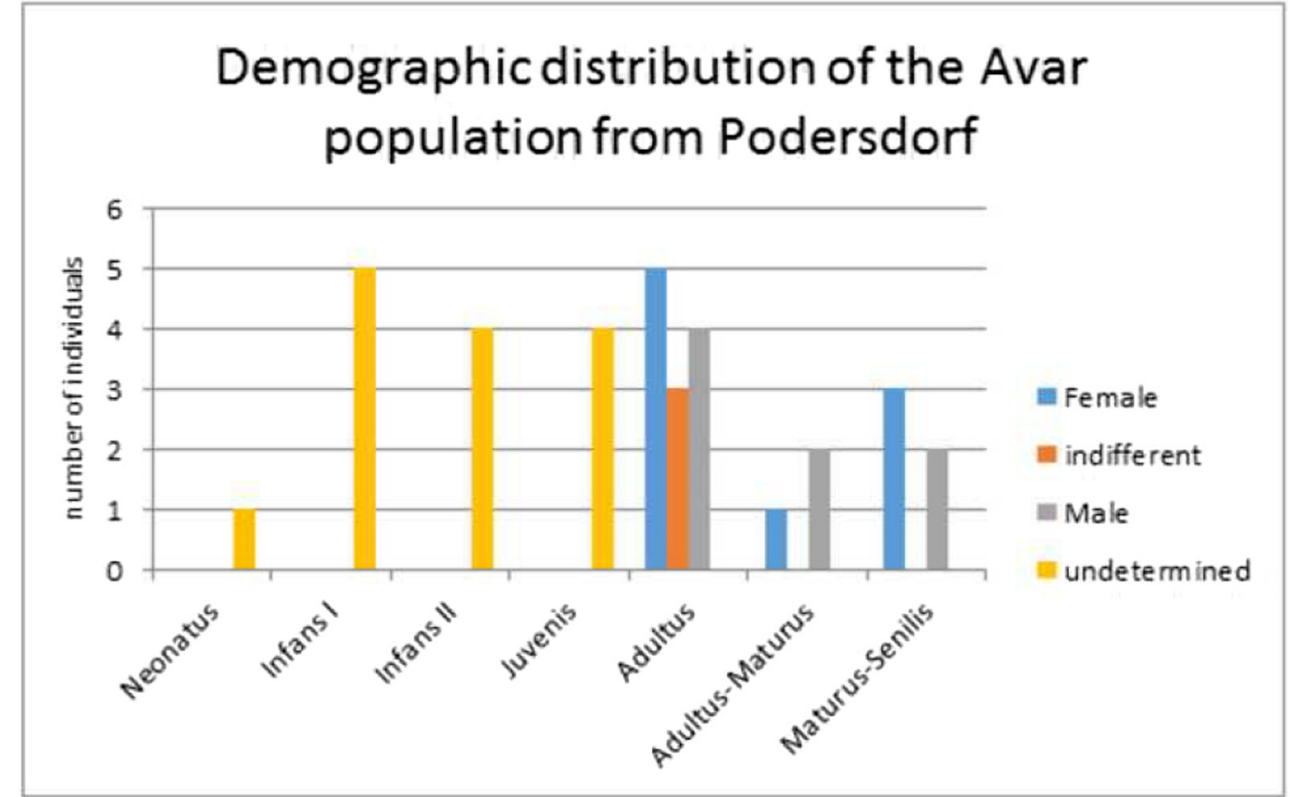

\section{Anthropological results}

The macroscopic examination of the five individuals from the pit house revealed the presence of one subadult (age 10-13 years) [crouched burial 2], two females (age 20-25 years [crouched burial 1] and 25-40 years [grave 41]), one male (age 25-35 years [grave 42]) and one adult with undetermined sex (age 20-25 years [grave 43]). Besides the demographic analysis of the sample, the research primarily focused on a morphological comparison with those from the burial ground, examining possible indications of different socio-economic or ethnic affiliation of the individuals in the house. The anthropological analysis of the whole sample therefore included the common assessment of sex and individual age at death (Acsádi and Nemeskéri 1970; Brooks and Suchey 1990; Lovejoy et al. 1985; Rösing 1977) as well as the reconstruction of body height (Trotter and Gleser 1952). In addition, a paleopathological examination was conducted on the skeletal remains from the excavation in 2017, including the burials inside the pit house (Ortner 2003; Waldron 2008).

The demographic profile of the 39 individuals examined so far corresponds to a normal living population, including both adult men and women as well as children (Fig. 10). The sex ratio among the adults is balanced with 10 male and 10 female identified individuals, whereas the age-at-death distribution has a broad range, with a remarkable, although not uncommon, high number of subadult individuals who died before the age of 6 . The majority of adult individuals died between the age of 20 and 40.

While the individuals from the pit house do not deviate from the demographic distribution, there is a noticeable difference in the state of bone preservation. Unlike the inhumations inside the house and in the nearby grave 40 , the majority of the skeletal remains from the burial ground display a high degree of fragmentation and cortical erosion, which are mainly due to systematic grave robbing of the burial site. Apart from this postmortem destruction, there is no macroscopic evidence of any morphological variation between the individuals buried inside and outside the house. The mean body height of $169.6 \mathrm{~cm}$ of the sample from the pit house corresponds to that of the individuals from the burial ground. Furthermore, sexual dimorphism exists in both samples, according to which male individuals are, on average, taller and show higher skeletal robustness and pronounced musculoskeletal stress markers on the long bones of the upper and lower limbs than the females. Hence, as entheseal changes seem to arise from excessive physical stress, specific activities and occupational patterns may be associated therewith (Martin et al. 2013).

The specific paleopathological examination of the individuals from the pit house revealed skeletal evidence of nonspecific inflammatory or infectious processes. As an example, the male individual of grave 42 displays multiple changes on the skull and postcranium, which mainly point to previous traumatic events. As depicted, the unhealed lesion and active new bone formation on the left maxilla (Fig. 11) indicate active inflammation of the surrounding tissue during his lifetime. Dental pathologies of the right upper teeth further imply unilateral food consumption due to permanent pain. The same individual also shows marked new bone formation on the right tibia and fibula, suggesting chronic, posttraumatic periostitis of the bones (Fig. 12). In contrast to the skeletal evidence of intravital injuries and traumata, the cause of death could only be presumed in one case: the male individual in grave 40 . 


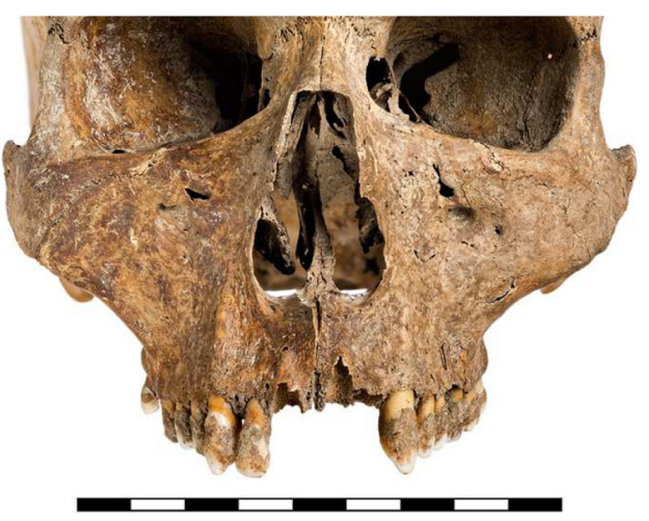

Fig. 11 Infraorbital lesion with new bone formation on the left upper maxilla (photo: W. Reichmann, NHM)

Multiple unhealed lesions on the ventral surface of the left ribs indicate an active pulmonary infection at the time of death (Fig. 13).

In terms of the dental status of the sample, it can be established that moderate attrition and calculus, which may be associated with dietary composition, thus indicating a fibre-rich diet of the population, are the main pathologies. Two individuals from the house (grave 42 , crouched burial 2) additionally exhibit severe occlusal carious lesions (Fig. 14), which are quite uncommon in Avar populations and
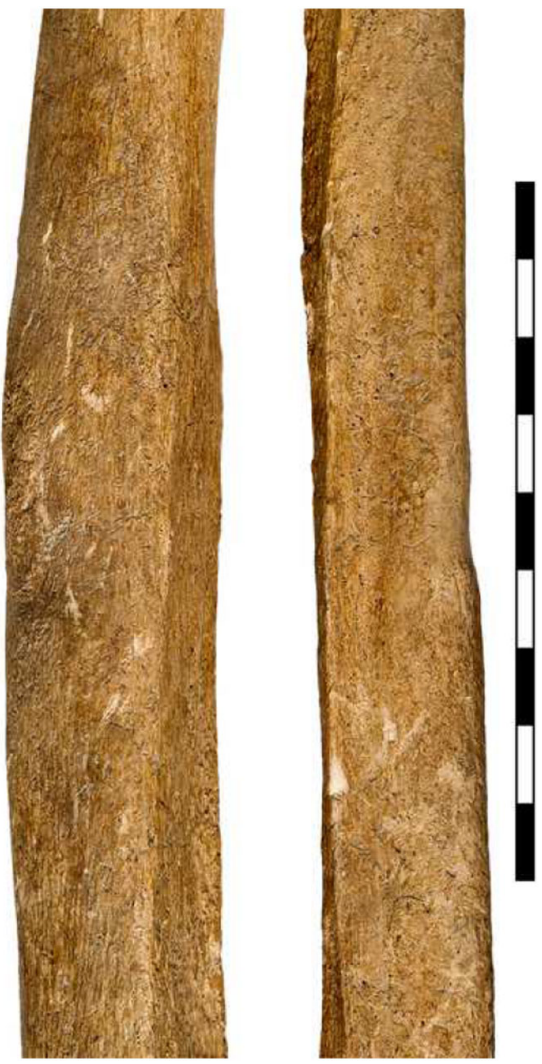

Fig. 12 Diaphyses of the right tibia and fibula with marked periosteal reactions, indicating chronic inflammation (photo: W. Reichmann, NHM)

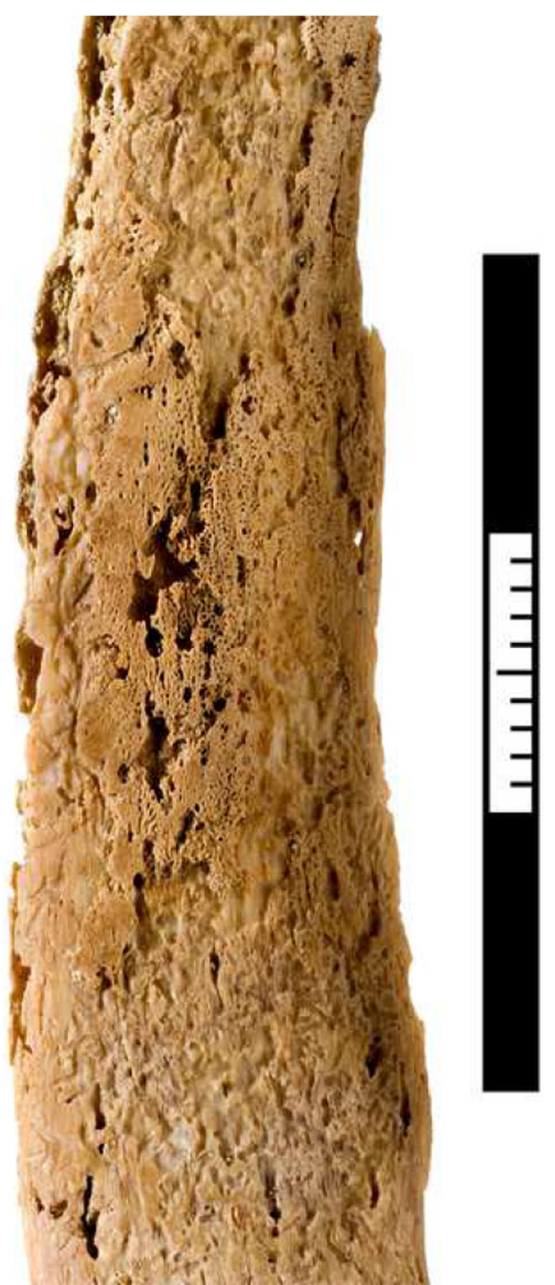

Fig. 13 New woven bone formation on the ventral surface of the rib, caused by an active pulmonary disease (photo: W. Reichmann, NHM)

especially remarkable considering the young age (10-13 years) of one of the individuals.

Both individuals were buried next to each other, which further raises the question of whether there is a social or

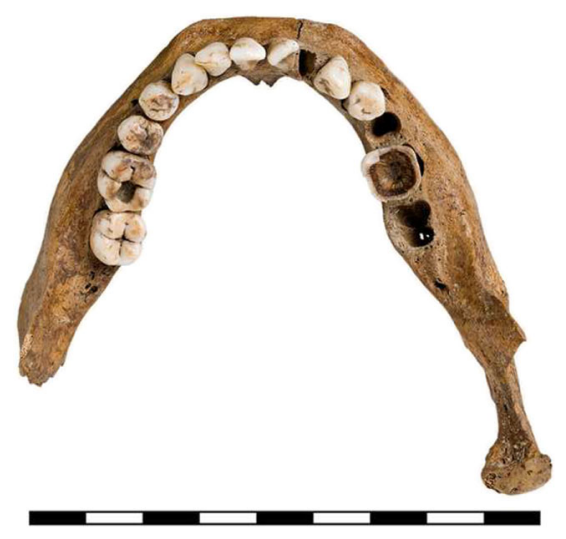

Fig. 14 Mandible of the subadult individual: severe occlusal caries lesions of the molars, right side more affected (photo: W. Reichmann, NHM) 
genetic link between them. The similar distribution and severity of caries could be based on predisposition or even on a shared variant nutrition. Further dental examinations revealed shovel-shaped upper incisors. This non-metric trait is still common in, but not limited to, modern populations of North-East Asia and is associated by extension with Avar ancestry and the ethnic affiliation of the population from Podersdorf (Kimura et al. 2009). The prevalence of such shovel-shaped teeth in the whole sample further implies a genetic relationship.

In summary, the anthropological results from the individuals in the pit house are consistent with those of the previous excavations in Podersdorf. Despite the small sample size from 2017, the demographic profile is the same, and although additional paleopathological examinations revealed some individual changes and abnormalities, the comparison of both burial sites suggests an overall macroscopically homogenous population sample. In conclusion, the anthropological analysis neither does imply different social or ethnic groups nor does it offer an explanation for the separate inhumations inside the house.

\section{Ancient DNA analysis}

A total of five solid skeletal remains (one femur, four teeth) were subjected to ancient DNA (aDNA) analysis according to the protocol published in Parson et al. (2018). In brief, the surfaces of the specimens were mechanically cleaned using a Dremel ${ }^{\circledR}$ tool and chemically cleaned using a $5 \%$ bleach solution. The samples were carefully drilled with a dental drill at low speed to prevent overheating, the roots and a portion of the femur were subjected to milling in a Retsch ${ }^{\circledR}$ ball mill MM400 (Retsch GmbH, Haan, Germany). The resulting powder was lysed and DNA was extracted following the protocol described in Loreille et al. (2007). Estimation of the mitochondrial DNA (mtDNA) copy number was performed using a tetraplex real-time PCR quantitation system (manuscript in preparation). Specimens that showed the highest mtDNA yields were further used (Table 3). Samples HD317 (crouched burial 1) and HD435.1 (crouched burial 2) were directly subjected to sequencing library preparation using the Ion Xpress ${ }^{\mathrm{TM}}$ Fragment Library Kit (Thermo Fisher Scientific (TFS)) according to the manufacturer's protocol and as described in Eduardoff et al. (2017). Samples HD41.3 (grave 41), HD42.2 (grave 42) and HD43.2 (grave 43) were amplified with the Precision ID mtDNA Whole Genome Panel (TFS, concept see Strobl et al. 2018) following the manufacturer's recommendations. All libraries were sequenced on the Ion S5 ${ }^{\mathrm{TM}}$ (TFS) with automated template preparation using the Ion Chef ${ }^{\mathrm{TM}}$ pipeline (TFS) according to the manufacturer's protocol. Raw data analysis was performed by means of the Ion Torrent ${ }^{\mathrm{TM}}$ Server analysis pipeline. MtDNA sequence variants were manually reported relative to the rCRS (revised Cambridge Reference Sequence, Andrews et al. 1999) based on phylogenetic alignment considerations according to Bandelt and Parson (2008) and Parson et al. (2014). Polynucleotide C-stretches were not analysed. Haplogroups were determined based on PhyloTree Build 17 (www.phylotree.org; van Oven and Kayser 2009) using the haplogrouping function in EMPOP (https:// empop.online; Parson and Dür 2007; Huber et al. 2018).

Nuclear DNA yields were low (Table 4) and resulted in clear genetic sexing only in the case of sample HD41.3, indicating female sex. The other samples did not yield enough nuclear DNA for unambiguous sex determination. The mtDNA analyses were more successful. Individuals HD42.2 and HD453.1 yielded the same mitotype, suggesting that the individuals could be (closely) maternally related. The mitotype belonged to haplogroup U5a2a that is of West-Eurasian provenience. It arose around 6,000 years ago and was also found in an ancient Mesolithic sample $(6,000-5,000 \mathrm{BCE})$ in the Basque country (Palencia-Madrid et al. 2017).

Table 3 Summary of specimens analysed in this study. Nuclear DNA (nDNA) and mitochondrial DNA (mtDNA) quantities are listed (mitochondrial genome equivalents (mtGE)). Molecular genetic methods are shown in the last two columns (drawing: Christina Strobl, Walther Parson)

\begin{tabular}{llllllll}
\hline ID & Sample & nDNA $(70 \mathrm{bp}) \mathrm{ng} / \mathrm{ul}$ & $143 \mathrm{bp} \mathrm{mtGE/ul}$ & $67 \mathrm{bp} \mathrm{mtGE/ul}$ & Genetic sexing & mitoTiling & PEC \\
\hline HD317 & Femur & 0.002 & 7.35 & 76.62 & $?$ & Full CR \\
HD41.3 & Tooth loose & 0.105 & 366.93 & 3816.02 & Female & Full profile & - \\
HD42.2 & Tooth loose & 0.098 & 1200.34 & 4312.86 & Female & Full profile & - \\
HD43.2 & Tooth lower jaw & 0.005 & 1334.26 & 4957.82 & $?$ & Full profile & - \\
HD453.1 & Tooth loose & 0.003 & 185.76 & 735.4 & $?$ & - \\
HD-01-Ref & Buccal swab & n.a. & n.a. & n.a. & n.a. & Full CR \\
HD-02-Ref & Buccal swab & n.a. & n.a. & n.a. & n.a. & Full profile & n.a. \\
\hline
\end{tabular}


Table 4 Summary of mtDNA results obtained for the analysed samples and contamination controls. Haplogroup estimates are followed by sequence range and mitotype listed relative to the reference sequence (drawing: Christina Strobl, Walther Parson)

\begin{tabular}{|c|c|c|c|}
\hline ID & Haplogroup & Range & Mitotype \\
\hline HD317 & H1ap1 & $\begin{array}{l}1-9212126-23663690-38813959-41854455-4768 \\
4828-56958094-946610720-1141611542-12648 \\
12833-1297813127-1489215234-16569\end{array}$ & $\begin{array}{l}\text { 152C 263G 315.1C 750G 8410T 8860G 15326G 16189C } \\
\text { 16519C }\end{array}$ \\
\hline HD41.3 & U3a & $1-16569$ & $\begin{array}{l}\text { 73G 150T 152C 263G 315.1C 750G 1438G 1661G 1811G } \\
\text { 2294G 2706G 2850C 4703C 4769G 6518T 7028T 7245G } \\
\text { 8281del 8282del 8283del 8284del 8285del 8286del } \\
\text { 8287del 8288del 8289del 8860G 9266A 10506G 11467G } \\
\text { 11719A 12308G 12372A 13934T 14139G 14766T } \\
\text { 15019C 15326G 15454C 16343G 16390A 16519C }\end{array}$ \\
\hline HD42.2 & U5a2a & $1-16569$ & $\begin{array}{l}\text { 73G 151T 263G 315.1C 750G 1438G 2706G 3197C 4769G } \\
\text { 7028T 7853A 8860G 9477A 11467G 11719A 12308G } \\
\text { 12372A 12406A 13617C 14766T 14793G 15326G } \\
\text { 16114A 16256T 16270T 16294T 16526A }\end{array}$ \\
\hline HD43.2 & U5a1b1c & $1-16569$ & $\begin{array}{l}\text { 73G 263G 315.1C 750G 1187C 1438G 2706G 3197C } \\
\text { 4769G 7028T 8860G 9055A 9477A 9667G 9983G } \\
\text { 11467G 11719A 12308G 12372A 13617C 14766T } \\
\text { 14793G 15218G 15326G 16192T 16256T 16270T } \\
\text { 16291T 16399G }\end{array}$ \\
\hline HD453.1 & U5a2a & $\begin{array}{l}1-9331573-25433134-57335885-62386344-6698 \\
\quad 6982-98629988-1016610220-1034710489-14945 \\
15228-16569\end{array}$ & $\begin{array}{l}\text { 73G 151T 263G 315.1C 750G 3197C 4769G 7028T 7853A } \\
\text { 8860G 9477A 11467G 11719A 12308G 12372A 12406A } \\
\text { 13617C 14766T 14793G 15326G 16114A 16256 T } \\
\text { 16270T 16294T 16526A }\end{array}$ \\
\hline HD-01-Ref & $\mathrm{H} 2 \mathrm{a} 2 \mathrm{a} 1$ & $1-16569$ & $315.1 \mathrm{C} 10463 \mathrm{C}$ \\
\hline HD-02-Ref & $\mathrm{J} 1 \mathrm{c} 3$ & $1-16569$ & $\begin{array}{l}\text { 73G 185A 263G 295T 315.1C 462T 489C 750G 1438G } \\
\text { 2706G 3010A 4216C 4769G 5530T 7028T 7855T 8388C } \\
\text { 8460G 8860G 10398G 11251G 11719A 12063T 12612G } \\
\text { 13708A 13934T 14766T 14798C 15326G 15452A } \\
\text { 16069T 16126C }\end{array}$ \\
\hline
\end{tabular}

Individual HD317 yielded a haplogroup H1ap1 mitotype that is nested in superhaplogroup H, West-Eurasia's most frequent haplogroup.

Individual HD41.3 resulted in a haplogroup U3a mitotype. This haplogroup arose between 18,000 and 26,000 years ago and has been reported in Europe since at least 6,000 years (Salamon et al. 2010).

Individual HD43.2 yielded a haplogroup U5a1b1c mitotype. This haplogroup is dated between 3,000 and 7,000 years and has been found in Europe.

\section{Discussion}

Within the framework of this study relating to the pit house of Podersdorf am See, we were able to prove, for the first time in Austria, a settlement from the time of the late fifth and sixth centuries.

It could also be demonstrated that the burials were dug inside the house at a time at which regular burials were carried out in the immediate vicinity. The aDNA analyses also show that the individuals buried in the foetal position may not be considered separately, as kinship relationships with neighbouring burials may exist, as in the case of Podersdorf. Although the new findings do not provide any explanation for the different position, they are nevertheless groundbreaking for future interpretations. In general, the surrounding "regular" burials should always be included in future interpretations of burials in foetal position.

Acknowledgements We would like to thank the University of Innsbruck's Jubilee Fund for the promotion and support of our project and the community of Podersdorf am See, Austria, for their support. We would also like to give thanks to Mayra Mayr-Eduardoff for administrative support, Bettina Zimmermann for the independent analysis of the mtDNA data and Nina Payr for technical support (all Institute of Legal Medicine, Medical University of Innsbruck). Special thanks to Theresa Hinterkörner for her help.

Funding information Open access funding provided by University of Innsbruck and Medical University of Innsbruck.

Open Access This article is licensed under a Creative Commons Attribution 4.0 International License, which permits use, sharing, adaptation, distribution and reproduction in any medium or format, as long as you give appropriate credit to the original author(s) and the source, provide a link to the Creative Commons licence, and indicate if changes were made. The images or other third party material in this article are included 
in the article's Creative Commons licence, unless indicated otherwise in a credit line to the material. If material is not included in the article's Creative Commons licence and your intended use is not permitted by statutory regulation or exceeds the permitted use, you will need to obtain permission directly from the copyright holder. To view a copy of this licence, visit http://creativecommons.org/licenses/by/4.0/.

\section{References}

Acsádi G, Nemeskéri J (1970) History of Human life span and mortality. Akadémiai, Budapest

Andrews RM, Kubacka I, Chinnery PF, Lightowlers RN, Turnbull DM, Howell N (1999) Reanalysis and revision of the Cambridge reference sequence for human mitochondrial DNA. Nat Genet 23(2):147

Balogh CS (2016) Régészeti adatok a Duna-Tisza közi avarok történetéhez. (The History of the Avars in the Danube-Tisza Interfluve as Reflected in the Archaeological Record). Studia ad Archaeologiam Pazmaniensiae 6. Archaeolingua, Budapest.

Bandelt HJ, Parson W (2008) Consistent treatment of length variants in the human mtDNA control region: a reappraisal. Int $\mathrm{J}$ Legal Med 122(1):11-21

Beilke-Voigt I (2008) Kindergräber in frühgeschichtlichen Hausbefunden Norddeutschlands und Dänemarks. Bauopfer oder Bestattungen? In: Kümmel C, Schweizer B, Veit U (eds), Körperinszenierung, Objektsammlung, Monumentalisierung. Totenritual und Grabkult in frühen Gesellschaften. Archäologische Quellen in kulturwissenschaftlicher Perspektive. Tübinger Archäologische Taschenbücher 6. Waxmann, Münster 2008:537562

Beilke-Voigt I (2009) Menschliche "Bauopfer". Ein archäologischhistorischer Überblick. Ethnogr Archäol Z 50(1-2):67-78

Beljak J, Kolník T (2008) Germanic settlement from the Late Roman and Early Migration periods in Štúrovo. In: Niezabitowska-Wiśniewska B, Juściński M, Łuczkiewicz P, Sadowski S (eds) The turbulent Epoch. New materials from the Late Roman Period and the Migration Period, Monumenta Studia Gothica, vol 5. Instytut Archeologii UMCS, Lublin, pp 65-87

Bende L (2017) Temetkezési szokások a Körös-Tisza-Maros közén az avar kor második felében. (Bestattungsbräuche in der zweiten Hälfte der Awarenzeit im Gebiet zwischen Körös, Theiss und Maros). Studia ad Archaeologiam Pazmaniensiae 8. Archaeolingua, Budapest.

Blesl C, Preinfalk F (2007) KG Seebarn am Wagram. Fundber Österreich 45(2006):36-37

Bocsi Zs (2008) Die Keramik aus zwei spätantiken Siedlungen am Balaton: Ordacsehi-Kis-töltés und Zamárdi-Kútvölgyi-dülö, Komitat Somogy, Ungarn. In: Bemmann J, Schmauder M (eds) Kulturwandel in Mitteleuropa. Langobarden - Awaren - Slawen. Akten der Internationalen Tagung in Bonn vom 25. bis 28 . Februar 2008, Kolloquien zur Vor- und Frühgeschichte, vol 11. Rudolf Habelt, Bonn, pp 415-430

Blesl C, Preinfalk A, Preinfalk F (2009) KG Großengersdorf, MG GroßEngersdorf, VB Mistelbach. Fundber Österreich 47(2008):20

Brather S (2007) Wiedergänger und Vampire? Bauch- und Seitenlage bei westslawischen Bestattungen des 9. bis 12. Jh. In: Jeute GH, Schneeweiß J, Theune C (eds), Aedificatio terrae. Beiträge zur Umwelt- und Siedlungsarchäologie Mitteleuropas. Festschrift für Eike Gringmuth-Dallmer zum 65. Geburtstag. Internationale Archäologie. Studia honoraria 26. Leidorf, Rahden/Westf., pp 109-117
Brooks S, Suchey JM (1990) Skeletal age determination based on the os pubis: a comparison of the Acsádi-Nemeskéri and Suchey-Brooks methods. Hum Evol 5:227-238

Budai Balogh T (2009) Pannonische Grubenhäuser, Abriss der Römerzeitlichen Geschichte der eingetieften Wohnhäuser. In: Bíró Sz (ed) Ex officina... Studia in honorem Dénes Gabler. Mursella, Györ, pp 77-100

Cseh J. (1999) Régészeti adalékok egy zayva-parti gepida településről (Falusi parasztgazdaságok a Tisza mentén az V-VI. század fordulóján). In: A Gepidák. Kora középkori germán királyság az Alföldön - Ein frühmittelalterliches germanisches Königreich auf den grossen ungarischen Tiefebene, Gyulai katalógusok 7. Gyula, pp 39-57.

Distelberger A (1999) Awarinnen. Frauengräber des 7. und 8. Jahrhunderts n. Chr. in Österreich, PhD-Thesis, Wien.

Eduardoff M, Xavier C, Strobl C, Casas-Vargas A, Parson W (2017) Optimized mtDNA Control Region Primer Extension Capture Analysis for Forensically Relevant Samples and Highly Compromised mtDNA of Different Age and Origin. Genes (Basel) $8(10)$

Franz N, Schwarzäugel J, Tögel A, Tögel W (2015) KG Weiden am See, MG Weiden am See, Fundber. Österreich 53(2014):173-174

Grömer K (2015) Awarische Textilien aus den Gräbern von Zwölfaxing II (Burstyn-Kaserne). In: Müller S, Das awarische Gräberfeld in Zwölfaxing, Burstyn-Kaserne. Archäologische Forschungen in Niederösterreich 14, NÖ Institut für Landeskunde, St. Pölten, pp 192-207.

Herdits H (ed.) (2019) Neue Strassen auf alten Pfaden. Archäologie und Straßenbau im Burgenland, Landesmuseum Burgenland, 23. Februar bis 11. November 2018. Burgenländisches Landesmuseum - Katalog Neue Folge 53. Landesmuseum Burgenland, Eisenstadt.

Hincker V (2007) Un habitat aristocratique en Neustrie. Le site du château à Biéville-Beuville (Calvados, Normandie). In: Verslype L. (ed), Villes et campagnes en Neustrie. Sociétés-Economies Territoires-Christianistation. Actes des $\mathrm{XXV}^{\mathrm{e}}$ Journées Internationales d'Archéologie Mérovingienne de l'A.F.A.M, europe médiévale 8. Mergoil, Montagnac, pp 175-189.

Huber N, Parson W, Dur A (2018) Next generation database search algorithm for forensic mitogenome analyses. Forensic Sci Int Genet 37:204-214

Hundt HJ (1987) Textilreste aus awarischen Gräbern von Leobersdorf und ein Exkurs über gegossene Textilstrukturen an der Rückseite bronzener Riemenzungen. In: Daim F, Das awarische Gräberfeld von Leobersdorf, NÖ. Studien zur Archäologie der Awaren 3/2. Österreischische Akademie der Wissenschaften, Wien, pp 9-17.

Jedlicka F, Schmidt F (1999) KG Drösing. Fundber Österreich 37 (1998): 779.

Kimura R, Yamaguchi T, Takeda M, Kondo O, Toma T, Haneji K, Hanihara T, Matsukusa H, Kawamura S, Maki K, Osawa M, Ishida H, Oota H (2009) A common variation in EDAR is a genetic determinant of shovel-shaped incisors. Am J Hum Genet 85(4):528 535

Kiss V (2007) Zamárdi-Kútvölgyi-dülö. In: Belényesy K (ed), Gördülő indő. Régészeti feltárások az M7-es autópálya Somogy megyei szakaszán Zamárdi és Ordacsehi között. Budapest 2007:61-71

Kolník T (1998) Haus und Hof im quadischen Limesvorland. In: Leube A (ed), Haus und Hof im östlichen Germanien, Tagung Berlin vom 4. bis 8. Oktober 1994. Universitätsforschung zur Prähistorischen Archäologie 50. Rudolf Habelt, Bonn, pp 144-159.

Kulcsár V (1998) A kárpát-medencei szarmaták temetkezési szokásai. Aszód.

Leube A (2009) Studien zu Wirtschaft und Siedlung bei den germanischen Stämmen im nördlichen Mitteleuropa während des 1. bis 5./6. Jahrhunderts n. Chr. Römisch-Germanische Forschungen 64. Philipp von Zabern, Mainz. 
Loreille OM, Diegoli TM, Irwin JA, Coble MD, Parsons TJ (2007) High efficiency DNA extraction from bone by total demineralization. Forensic Sci Int Genet 1(2):191-195

Lovejoy CO, Meindl RS, Pryzbeck TR, Mensforth RP (1985) Chronological metamorphosis of the auricular surface of the ilium: A new method for the determination of adult skeletal age at death. Am J Phys Anthropol 68:15-28

Martin DL, Harrod RP, Perez VR (2013) Bioarchaeology: An integrated approach to working with human remains. Springer, New York

Milella M, Mariotti V, Belcastro MG, Knüsel CJ (2015) Patterns of Irregular Burials in Western Europe $\left(1^{\text {st }}-5^{\text {th }}\right.$ Century A.D.). PloS one 10(6): 0130616

Müller R (2012) Késő népvándorlás kori gödörházba temetett halott Alsópáhokról. (Late Migration period burial in a semisubterranean house at Alsópáhok). In: Kvassay J (ed), Évkönyv és jelentés a Kulturális Örökségvédelmi Szakszolgálat 2010. évi feltárásairól. (Field service for cultural heritage 2010 yearbook and review of archaeological investigations). Kulturális Örökségvédelmi Szakszolgálat, Budapest, pp 461-484.

Müller K (2018) Siedlungsinterne Bestattungen im frühmittelalterlichen Süddeutschland. Z Archäol Mittelalt 45(2017):33-102

Nice A (1994) L'habitat mérovingien de Goudelancourt-les-Pierrepont (Aisne). Aperçu provisoire d'une unité agricole et domestique des $\mathrm{VI}^{\mathrm{e}}$ et $\mathrm{VII}^{\mathrm{e}}$ siècles. Rev archéol Picardie 1-2:21-63

Nießen I (2012) "Sonderbestattungen" der Merowingerzeit in Süddeutschland. Grin, München

Nowotny E (2014) Rugier und Heruler. Die Ostgermanen von Schletz. In: Lauermann E (ed), Schatz-Reich Asparn. Ur- und Frühgeschichte und Mittelalter-Archäologie in Niederösterreich Ausstellungskatalog MAMUZ Schloss Asparn/Zaya, 2014. MAMUZ Museumszentrum-Betriebs $\mathrm{GmbH}$, Asparn an der Zaya, pp 246-249.

Obenaus M (2010) Arpadenzeitliche Gräberfelder und Grabfunde des 10. bis 12. Jahrhunderts in Ostösterreich. Fundmaterialien des Burgenländischen und Niederösterreichischen Landesmuseums. Wissenschaftliche Arbeiten aus dem Burgenland 135. Eisenstadt.

Obenaus M (2015) KG Thunau am Kamp, MG Gars am Kamp. Fundber Österreich 53(2014):238-240

Ódor JG (2001) V. századi település és temető Mözs határában. In Gáal, A. (ed), Tolna megye évszázadai a régészet tükrében. Szekszárd 2001, pp 33-34.

Ódor JG (2011) The $5^{\text {th }}$-century cemetery and settlement at Mözs (tolna County, Hungary) - some issues concerning the "East-Germanic" period in Transdanubia. (Gräberfeld und Siedlung des 5. Jahrhunderts in Mözs (Komitat Tolna, Ungarn) - Bemerkungen zur "ostgermanischen" Periode in Transdanubien). In: HeinrichTamáska O (ed), Keszthely-Fenékpuszta im Kontext spätantiker Kontinuitätsforschung zwischen Noricum und Moesia. Castellum Pannonicum Pelonense 2. Leidorf, Rahden/Westf., pp 347-359.

Ortner DJ (2003) Identification of pathological conditions in human skeletal remains. Academic, Amsterdam

Ottományi K (2015) In den Boden eingetiefte Häuser im Vicus von Budaörs. In: Bíró Sz, Molnár A (eds), Ländliche Siedlungen der römischen Kaiserzeit im mittleren Donauraum. Mursella: pp 119167.

Palencia-Madrid L, Cardoso S, Keyser C, López-Quintana JC, GuenagaLizasu A, de Pancorbo MM (2017) Ancient mitochondrial lineages support the prehistoric maternal root of Basques in Northern Iberian Peninsula. Eur J Hum Genet 25(5):631-636

Párducz M (1949) Népvándorláskori ház Mohácsról. Archaeol Értesitő 76:85-89

Parson W, Dür A (2007) EMPOP-a forensic mtDNA database. Forensic Sci Int Genet 1(2):88-92

Parson W, Gusmao L, Hares DR, Irwin JA, Mayr WR, Morling N, Pokorak E, Prinz M, Salas A, Schneider PM, Parsons TJ (2014) DNA Commission of the International Society for Forensic
Genetics: revised and extended guidelines for mitochondrial DNA typing. Forensic Sci Int Genet 13:134-142

Parson W, Eduardoff M, Xavier C, Bertoglio B, Teschler-Nicola M (2018) Resolving the matrilineal relationship of seven Late Bronze Age individuals from Stillfried, Austria. Forensic Sci Int Genet 36: $148-151$

Pohl W (1988) Die Awaren. Ein Steppenvolk in Mitteleuropa 567 - 822 n. Chr., Beck, München.

Pollak M (2017) Spätantike und Merowingerzeit in den beiden norischen Provinzen. Ein erster Blick auf den ostgotenzeitlichen Friedhof von Globasnitz/Globasnica, Kärnten. In: Dörfler I, Gleirscher P, Ladstätter S, Pucker I (eds), Ad amussim. Festschrift zum 65. Geburtstag von Franz Glaser. Kärntner Museumsschriften 85. Landesmuseum für Kärnten, Klagenfurt, pp 249-276.

Preinfalk A, Preinfalk F, Keller C (2013) Eine neu entdeckte spätantike Siedlung in Trasdorf. Archäol Österreich 24(2):38-45

Puschnigg G (1996) Ein spätantikes Gräberfeld in Oggau. Wiss Arbeiten Burgenland 96:59-126

Rösing F (1977) Methoden und Aussagemöglichkeiten der anthropologischen Leichenbrandbearbeitung. Archäol und Naturwissenschaften 1:53-80

Salamon M, Tzur S, Arensburg B, Zias J, Nagar Y, Weiner S, Boaretto E (2010) Ancient mtDNA sequences and radiocarbon dating of human bones from the chalcolithic caves of Wadi El-Makkukh (PDF). Mediterr Archaeol and Archaeometr 10(2):1-4

Schmidt B, Gruhle W, Rück O, Freckmann K (2005) Zur Dauerhaftigkeit bandkeramischer Häuser im Rheinland (5300-4950 v. Chr.) - Eine Interpretation dendorchronologischer und bauhistorischer Befunde. In: Gronenborn D. (ed.), Klimaveränderung und Kulturwandel in neolithischen Gesellschaften Mitteleuropas, 6700 - 2200 v. Chr. (Climate variability and culture chance in neolithic societies of Central Europe, 6700 - 2200 cal BC). RGZM-Tagungen 1, Mainz, pp 151-170.

Schoenenberg V (2018) Siedlungen im alemannischen Raum. Das Beispiel Lauchheim. In: Brather S, Merthen C, Springer T (eds), Warlords oder Amtsträger? Herausragende Bestattungen der späten Merowingerzeit. Beiträge der Tagung im Germanischen Nationalmuseum in Zusammenarbeit mit dem Institut für Archäologische Wissenschaften (IAW) der Albert-LudwigsUniversität Freiburg, Abt. Frühgeschichtliche Archäologie und Archäologie des Mittelalters, 21.-23.10.2013. Wissenschaftliche Beibände zum Anzeiger des Germanischen Nationalmuseums Band 41, Nürnberg, pp 174-188.

Skriba P, Sófalvi A (2004) Langobard település Balatonlelle határában. (Eine Langobardensiedlung in der Gemarkung von Balatonlelle). Archaeol Értesitő 129:116-164

Somogyi K (2000) Előzetes jelentés a Kaposvár-61-es út elkerülő szakasz 1. számú lelőhelyén végzett feltárásról. (Preliminary report of the excvataion of Site No. 1. situated on the encircling section of Road 61 around Kaposvár). Somogyi Múz Közleményei 14:245-249

Stadler P (1981) Völkerwanderungszeitliche Funde: eine Siedlung bei Unterlanzendorf und ein Gräberfeld bei Rannersdorf, Niederösterreich. Archaeol Austriaca 65:139-185

Strobl C, Eduardoff M, Bus MM, Allen M, Parson W (2018) Evaluation of the precision ID whole MtDNA genome panel for forensic analyses. Forensic Sci Int Genet 35:21-25

Stuppner A (2013) Die ländliche Besiedlung im mittleren Donauraum von der Spätantike bis zum Frühmittelalter. Antiqu Tardive 21:4762

Tejral J (1998) Die Besonderheiten der germanischen Siedlungsentwicklung während der Kaiserzeit und der frühen Völkerwanderungszeit in Mähren und ihr Niederschlag im archäologischen Befund. In: Leube A (ed), Haus und Hof im östlichen Germanien. Tagung, Berlin vom 4. bis 8. Oktober 1994. Universitätsforschungen zur Prähistorischen Archäologie 50. Rudolf Habelt, Bonn, pp 181-207. 
Tobias B, Draganits E, Wiltschke-Schrotta K, Saliari K (2017) KG Podersdorf am See. MG Podersdorf am See. Fundber Österreich 54(2015):49-50

Tobias B, Koch Waldner T, Draganits E, Wiltschke-Schrotta K, Saliari K, Skomorowski K (2018) KG Podersdorf am See, MG Podersdorf am See. Fundber Österreich 55(2016): 64-65.

Tobias B, Saliari K, Draganits E, Musalek C, Wiltschke-Schrotta K, Koch Waldner T, Totschnig R, Strobl C, Niederstätter H, Parson W, Skomorowski R, Löcker K (2020). Das frühmittelalterliche Gräberfeld von Podersdorf am See (Burgenland, Ostösterreich). Veränderung der Bestattungssitten im diachronen Vergleich. In: Kühtreiber T, Risy R, Scharrer-Liška G, Theune C (eds), Leben mit dem Tod. Der Umgang mit Sterblichkeit in Mittelalter und Neuzeit. Beiträge der internationalen Tagung in St. Pölten 11. bis 15. September 2018. Beiträge zur Mittelalterarchäologie in Österreich 34(2020), Wien, pp 209-226.

Toplak MS (2017) Deviant burials und Bestattungen in Bauchlage als Teil der Norm. Eine Fallstudie am Beispiel der Wikingerzeit Gotlands. Frühmittelalterliche Stud 51(1):39-56

Tóth ÁB (2006) Gepidische Siedlungen im Theissgebiet. Monumenta Germanorum Archaeologica Hungariae 4. Magyar Nemzeti Múzeum, Budapest.

Trotter M, Gleser GC (1952) Estimation of stature from long bones of American Whites and Negroes. Am J Phys Anthropol 10:463-514 van Oven M, Kayser M (2009) Updated comprehensive phylogenetic tree of global human mitochondrial DNA variation. Hum. Mutat 30(2): E386-E394

Waldron T (2008) Palaeopathology. Cambridge University, New York Wawruschka C (2009) Frühmittelalterliche Siedlungsstrukturen in Niederösterreich. Mitteilungen der Prähistorischen Kommission 68. Österreichische Akademie der Wissenschaften, Wien.

Wirth K (2011) Ausgrabungen in Ivesheim, Mahrgrund II (RheinNeckar-Kreis). Funde und Befunde des 4./5. Jahrhunderts. In: Drauschke J, Prien R, Ristow S (eds), Untergang und Neuanfang. Tagungsbeiträge der Arbeitsgemeinschaft Spätantike und Frühmittelalter. 3. Siedlungsarchäologie (Mannheim, 13.-14. Mai 2008), 4. Militaria und Verteidigungsanlagen (Detmold, 1. September 2009). Studien zu Spätantike und Frühmittelalter 3. Kovač, Hamburg, pp 1-16.

Винокур İC, Мегей ВП (1992) Ювелірна майстерня раньосередньовічних слов'ян. (Jewelry Workshop of the Early Middle Ages Slavs). Arheol (Kiev) 3:82-95

Publisher's note Springer Nature remains neutral with regard to jurisdictional claims in published maps and institutional affiliations. 